\title{
Pertimbangan Hakim dalam Menjatuhkan Putusan Terhadap Anak yang Melakukan Tindak Pidana Pembunuhan
}

\author{
Altov Akmila Qotrunnada ${ }^{1}$, Mukhtar Zuhdy ${ }^{2}$ \\ 1,2 Fakultas Hukum, Universitas Muhammadiyah Yogyakarta \\ Email : 1altov.akmila.2015@law.umy.ac.id \\ ²mukhtarzuhdy@umy.ac.id
}

\section{Info Artikel}

\section{Kata Kunci :}

peradilan pidana anak, tindak pidana pembunuhan, pertimbangan hakim

\section{Perjalanan Artikel :}

Diterima : 15 Agustus 2020

Direview : 27 Agustus 2020

Direvisi : 29 Agustus 2020

Dipublikasikan : Agustus 2020

DOI: 10.18196/ijclc.v1i2.9646

\begin{abstract}
Abstrak
Kejahatan telah dikenal dalam peradaban manusia, kejahatan dapat dikatakan mempunyai umur yang tua. Salah satu kejahatan yang terjadi yaitu pembunuhan. Tindak pidana saat ini tidak hanya dilakukan orang dewasa saja, juga dilakukan anak-anak. Tujuan penelitian ini untuk mengetahui pertanggungjawaban pidana terhadap anak sebagai pelaku tindak pidana pembunuhan dan untuk mengetahui pertimbangan hakim dalam menjatuhkan putusan terhadap anak yang melakukan tindak pidana pembunuhan. Metode penelitian ini menggunakan metode penelitian normatif. Sumber data yang digunakan adalah sumber data sekunder yaitu data yang diperoleh dan dicatat oleh pihak lain serta bahan lain. Analisis data yang digunakan adalah analisis data kualitatif yaitu data yang dianalisis tidak terhitung, dengan menjelaskan dan menerangkan data dalam bentuk kalimatkalimat yang disusun dengan pokok bahasan secara sistematis. Hasil penelitian ini adalah Anak yang melakukan tindak pidana pembunuhan tidak dapat dikenai sanksi tindakan, tetapi dikenai sanksi pidana. Pasal 79 ayat (1) UU No. 11 Tahun 2012 tentang SPPA menyebutkan bahwa pidana pembatasan kebebasan diberlakukan dalam hal tindak pidana berat atau tindak pidana yang disertai dengan kekerasan. Anak yang melakukan tindak pidana pembunuhan tidak dapat didiversi. Pertimbangan Hakim dalam menjatuhkan putusan terhadap anak yang melakukan tindak pidana pembunuhan berdasarkan hal-hal yang memberatkan pada pelaku, sehingga pelaku dapat dijatuhi pidana sesuai perbuatannya.
\end{abstract}

\section{Pendahuluan}

Kejahatan telah dikenal dalam peradaban manusia, tak heran jika kejahatan dapat dikatakan mempunyai umur yang tua seperti manusia. Salah satu kejahatan yang terjadi yaitu pembunuhan. Pembunuhan sudah terjadi dari sejak zaman dahulu atau dapat dikatakan bahwa pembunuhan merupakan kejahatan yang mengikuti perkembangan budaya manusia dan kekerasan demi kekerasan dalam berbagai bentuknya mengancam jiwa manusia yang dilakukan oleh dan terhadap anak-anak manusia itu sendiri yang terus berlangsung hingga saat ini. ${ }^{1}$

Di Indonesia kejahatan secara umum diatur dalam Kitab Undang-Undang Hukum Pidana (KUHP) dalam buku kedua. Salah satu bentuknya yaitu pembunuhan, dalam KUHP pembunuhan tergolong dalam kejahatan terhadap nyawa yang diatur secara khusus dalam Bab XIX KUHP yang terdiri dari 13 pasal yaitu Pasal 338 sampai dengan Pasal 350. Selanjutnya kejahatan terhadap nyawa dibagi menjadi dua golongan yaitu berdasarkan unsur kesengajaan dan unsur kelalaian.

\footnotetext{
${ }^{1}$ J.E, Sahetapy, 1987, Victimologi Sebuah Bunga Rampai, Jakarta, Pustaka Sinar Harapan, hlm. 35-36.
} 
Tindak pidana saat ini tidak hanya dilakukan oleh orang dewasa saja, melainkan dapat juga dilakukan oleh anak-anak. Pembunuhan merupakan kejahatan yang berat dan cukup mendapatkan perhatian dari masyarakat. Berbagai macam berita di surat kabar, majalah bahkan internet juga sudah sering memberitakan terjadinya pembunuhan. Dalam hal ini sudah sepatutnya bagi orang tua untuk melindungi dan memperhatikan anaknya agar anak tersebut tidak melakukan hal yang terlarang terlebih sampai menghilangkan nyawa seseorang.

Undang-Undang Nomor 11 Tahun 2012 tentang Sistem Peradilan Pidana Anak, istilah anak nakal digantikan dengan istilah anak yang berhadapan dengan hukum. Dimana dalam bab 1 Pasal 1 butir 2 dikatakan bahwa: "Anak yang berhadapan dengan hukum adalah anak yang berkonflik dengan hukum, anak yang menjadi korban tindak pidana dan anak yang menjadi saksi tindak pidana". Selanjutnya dalam butir 3 disebutkan bahwa: "Anak yang berkonflik dengan hukum yang selanjutnya disebut Anak adalah anak yang telah berumur 12 (dua belas) tahun, tetapi belum berumur 18 (delapan belas) tahun, yang diduga melakukan tindak pidana".

Anak yang melakukan perbuatan kejahatan akan dimintai kemampuan untuk bertanggungjawab, karena anak tersebut telah melanggar hukum. Undang-Undang Nomor 35 Tahun 2014 tentang Perlindungan Anak menetapkan anak adalah seseorang yang belum berusia 18 (delapan belas) tahun, termasuk anak yang masih dalam kandungan. Anak yang berhadapan dengan hukum adalah anak yang telah melanggar undang-undang dan akan dikenai pertanggungjawaban pidana atas perbuatannya.

Pertanggungjawaban yang harus dibebankan kepada pelaku yang melakukan pelanggaran hukum pidana berkaitan dengan dasar untuk menjatuhkan sanksi pidana. Pengkategorian umur akan menentukan dapat dipidana atau tidaknya seorang anak dijatuhi hukuman, dan dapat tidaknya suatu tindak pidana dipertanggungjawabkan kepada seorang anak. ${ }^{2}$

Anak-anak sangat membutuhkan kasih sayang yang termasuk kebutuhan psikis yang merupakan kebutuhan mendasar bagi setiap manusia, terutama bagi anak. Perlindungan hukum anak atau perlindungan anak secara yuridis dapat meliputi perlindungan hukum anak dalam bidang hukum privat, dan dalam bidang hukum publik. Perlindungan hukum anak dalam bidang hukum publik diantaranya adalah perlindungan hukum anak secara materil dan perlindungan hukum anak secara formil. Hukum pidana formil yang berhubungan dengan peradilan pidana anak yang yang termasuk dalam peradilan umum. ${ }^{3}$

Berbicara tentang perlindungan anak, maka hal tersebut yang bertanggung jawab adalah orang tua, orang tua wajib bertanggung jawab untuk melindungi anak-anaknya. Selain orangtua, masyarakat di sekitar juga mempunyai kewajiban untuk bertanggungjawab dalam melindungi anak, dan juga lembaga-lembaga yang diberi wewenang oleh pengadilan serta pemerintah baik pusat maupun daerah, hal ini diatur dalam Pasal 20 sampai dengan Pasal 26 Undang-Undang Nomor 23 Tahun 2002 terutama terhadap anak-anak yang melanggar hukum.

Setelah keluarga yang menjadi salah satu penyebab anak melakukan tindak pidana, lingkungan sekolah dan lingkungan bermain anak juga dapat menjadi penyebab anak melakukan tindak pidana, sehingga lingkugan sekolah dan bermain anak juga harus terkontrol agar anak tidak sampai melakukan tindak pidana. Tidak semua anak yang melakukan tindak pidana adalah anak yang berasal dari keluarga tidak harmonis, ada juga anak yang melakukan tindak pidana berasal dari keluarga yang sangat harmonis, hal itu disebabkan karena faktor lingkungan anak-anak yang sangat berpengaruh dalam perilaku anak. ${ }^{4}$

Anak yang berasal dari keluarga yang tidak harmonis akan mencari tahu lingkungannya sendiri, sehingga apabila lingkungan tersebut positif maka anak tersebut akan melakukan hal positif juga, seperti dapat menyelesaikan masalahnya dengan baik tanpa melakukan hal-hal yang negatif, tetapi apabila anak tersebut menemukan lingkungan yang negatif, maka anak tersebut juga akan

\footnotetext{
${ }^{2}$ S.R Sianturi, 1996 Asas-Asas Hukum Pidana Indonesia Dan Penerapanya, Jakarta, Alumni Ahaem-Peteheam, hlm. 245.

${ }^{3}$ Safrizal, "Pertanggungjawaban Pidana dari Anak Dibawah Umur yang Melakukan Pembunuhan", Lex Crimen, Vol. 2, No. 7, (2013), hlm. 44.

${ }^{4}$ Syekh Khalid bin Abdurrahman, dkk, 2006, Cara Islam Mendidik Anak, cet 1 Yogyakarta, Ad Dawa', hlm. 99.
} 
melakukan hal yang negatif, salah satunya adalah melakukan tindak pidana seperti mencuri, merampok bahkan membunuh. Begitupun anak yang berasal dari keluarga yang harmonis akan lebih terkontrol dalam pergaulan, akan tetapi jika anak tersebut merantau atau jauh dari orang tua, anak tersebut akan mencari tahu lingkungannya sendiri. Faktor jauh dari orang tua juga dapat menyebabkan anak tersebut melakukan tindakan yang melanggar hukum.

Kedudukan keluarga sangatlah penting bagi anak, terutama dalam pendidikan anak, jika keluarga dalam mendidik gagal, maka anak cenderung akan berbuat nakal atau melakukan tindak pidana. B. Simanjuntak berpendapat bahwa kondisi-kondisi keluarga yang dapat menjadikan "anak nakal" adalah: ${ }^{5}$

1. Adanya anggota lain dalam rumah tangga tersebut sebagai penjahat, pemabuk, emosional.

2. Ketidakadaan salah satu kedua orangtua karena kematian, perceraian, atau pelarian diri.

3. Kurangnya pengawasan orangtua karena sikap masa bodoh, cacat inderanya, atau sakit jasmani atau rohani.

4. Ketidakserasian karena adanya main kuasa sendiri, iri hati, cemburu, terlalu banyak anggota keluarganya dan mungkin ada yang campur tangan.

5. Perbedaan raisial, suku, dan agama ataupun perbedaan adat istiadat, rumah piatu, panti-panti asuhan.

Perlu diketahui perbuatan kejahatan terhadap jiwa seseorang yang menimbulkan akibat matinya seseorang merupakan perbuatan yang dilarang dan diancam dengan hukuman oleh undangundang. Penyimpangan tingkah laku yang dilakukan oleh anak dapat disebabkan karena dampak negatif perkembangan pembangunan yang cepat, arus globalisasi dibidang informasi dan komunikasi, perkembangan ilmu pengetahuan dan teknologi dan juga perubahan gaya hidup orangtua sehingga membawa perubahan sosial dalam kehidupan masyarakat yang sangat berpengaruh terhadap perilaku manusia. Selain itu juga kurangnya perhatian dan kasih sayang, asuhan dan bimbingan dan pembinaan dalam pengembangan sikap perilaku penyesuaian diri, serta pengawasan dari orang tua, wali atau orang tua asuh akan udah terseret dalam arus pergaulan masyarakat yang lingkungan kurang sehat dan merugikan perkembangan pribadinya. ${ }^{6}$

Sanksi pidana yang diberikan kepada pelaku berdasarkan kebenaran, keadilan dan kesejahteraan. Penjatuhan pidana atau tindakan merupakan suatu tindakan yang harus bermanfaat bagi pelaku. Hakim harus mempertimbangkan keadaan rumah dan keadaan lingkungan dan laporan pembimbingan masyarakat.

\section{Rumusan Masalah}

Berdasarkan latar belakang yng telah penulisuraiak pada pendahuluan, maka rumusan masalah yang menjadi pokok penulisan adalah bagaimana pertimbangan hakim dalam menjatuhkan putusan terhadap anak yang melakukan tindak pidana pembunuhan.

\section{Metode Penelitian}

Penelitian ini menggunakan penelitian normatif dengan bersumber dari bahan hukum primer, bahan hukum sekunder dan bahan hukum tersier. Penulis juga melakukan wawancara dengan narasumber antara lain Bapak IPTU Archi (Penyidik pada POLRESTA Yogyakarta) dan Ibu Nenden Rika Puspitasari, S.H (Hakim Anak pada Pengadilan Negeri Yogyakarta. Data yang sudah diperoleh di analisis menggunakan pendekatan deskriptif kualitatif.

\section{Hasil Penelitian dan Analisis}

\footnotetext{
${ }^{5}$ B. Simanjuntak, 1984, Kriminologi, Bandung, Tarsito, hlm. 55.

${ }^{6}$ Supramono Gatot, 2000, Hukum Acara Peradilan Anak, Jakarta, Djambatan, hlm. 158
} 
Tindak pidana dalam Bahasa Belanda dikenal dengan istilah straafbaar feit. Didalam Kitab Undang-Undang Hukum Pidana (KUHP) tidak di temui definisi Tindak Pidana. Adami Chazawi telah menerjemahkan istilah straafbaar feit, yaitu secara sederhana dapat dijelaskan bahwa tindak pidana adalah perbuatan yang pelakunya harus dipidana. Tindak pidana dirumuskan dalam UndangUndang salah satunya KUHP. ${ }^{7}$

Tindak pidana dalam Bahasa Inggris diartikan dengan Crime Act, apabila seseorang melakukan kesalahan belum berarti ia dapat di pidana, tetapi adanya pertanggungjawaban atas perbuatannya yang disebut dengan Criminal Responsibility. ${ }^{8}$ Tindak pidana adalah perbuatan yang melanggar larangan yang diatur oleh hukum yang diancam dengan sanksi pidana. Dalam rumusan tersebut bahwa yang tidak boleh dilakukan adalah perbuatan yang menimbulkan akibat yang dilarang dan diancam sanksi pidana bagi orang yang melakukan pelanggaran tersebut. Menurut Andi Hamzah tindak pidana adalah perbuatan yang dilarang dan diancam dengan pidana oleh UndangUndang. ${ }^{9}$

Sebagai contoh kasus perkara tindak pidana pembunuhan yang dilakukan oleh anak dengan kronologis bermula pada hari Rabu tanggal 6 Juni 2018 sekitar jam 24.00 WIB pelaku dan saksi 1 nongkrong di bawah tiang lampu kuning di depan SMP Negeri 1 Yogyakarta, selanjutnya datang saksi 2 dengan mengendarai sepeda motor. Setelah beberapa menit mereka mengobrol, saksi 2 pergi membeli rokok di warung burjo, dan pelaku juga pamit untuk membeli bensin, sedangkan saksi 1 pergi menuju warung gudeg, tidak lama kemudian saksi 2 menyusul ke warung gudeg dan memesan kopi. Setelah itu saksi 2 pamit sebentar untuk buang air kecil di barat jalan. Pada saat itu juga datang rombongan (5) sepeda motor dari arah selatan langsung melempari batu ke arah saksi 1 dan saksi 2 sambil berteriak bajingan aku HTF (Holigan To Fight). Setelah itu rombongan langsung pergi ke arah utara lalu berbelok ke arah barat menuju perempatan mirota kampus. Melihat hal tersebut saksi 2 langsung masuk ke Hotel Limaran II untuk mengambil senjata tajam jenis bendo yang terbuat dari besi yang berada di sekitar taman hotel. Tidak lama kemudian datang rombongan 4 (empat) sepeda motor milik korban dan teman-temannya dari arah selatan yang melintas di depan saksi 2, kemudian saksi 2 menunggu pelaku datang. Setibanya pelaku kemudian saksi 2 langsung membonceng pelaku sambil berkata "ayoo ayoo" dan tangannya menunjuk ke arah rombongan korban yang baru saja lewat dan berbelok ke arah barat menuju simpang empat Mirota Kampus. Sesampainya di depan Mirota Kampus sebelum lampu merah, pelaku yang mengemudikan sepeda motor berusaha mendekati sepeda motor yang di kendarai oleh korban dan temannya, setelah berhasil mendekati sepeda motor korban dengan jarak kurang lebih $50 \mathrm{~cm}$ dari sebelah kiri, saksi 2 berteriak dan memukulkan senjata tajam berupa bendo tersebut sebanyak 1 (satu) kali dan mengenai punggung sebelah kiri. Kemudian teman korban ketika mendengar teriakan tersebut dan menengok ke belakang melihat pelaku sudah membawa senjata tajam, dikarenakan takut maka teman korban langsung tancap gas ke arah utara. Kemudian setelah berhasil melukai korban, pelaku berbalik arah menuju SMP Negeri 1 Yogyakarta. Dalam perjalanannya korban bercerita bahwa dia telah terkena bacok di bagian punggung sebelah kiri dan berdarah, kemudian mereka langsung menuju Rumah Sakit dr. Sardjito dan ke IGD untuk mendapatkan perawatan. Bahwa luka akibat pemukulan dengan menggunakan benda tajam jenis bendo mengakibatkan korban mengalami luka bacok di punggung sebelah kiri dan pada akhirnya korban meninggal dunia karena mengalami pendarahan di rongga dada sebagaimana Visum Et Revertum Nomor: 021/2018 tanggal 02 Juli 2018. Dari contoh kasus yang pertama ini maka pelaku di dakwa telah membantu menghilangkan nyawa orang lain dengan mengejar, memepetkan sepeda motor sehingga saksi 2 dapat melakukan pembacokan terhadap korban. Tuntutan yang diberikan kepada pelaku dengan pidana penjara selama 4 tahun di LPKA Kelas II Yogyakarta yang bertempat di Rutan Kelas II Wonosari dan dilakukan penahanan. Hal-hal yang Memberatkan dan Meringankan dalam Persidangan yaitu:

a. Hal-hal yang memberatkan: Bahwa anak telah melakukan pelanggaran Hukum (tindak pidana yang sama sebelumnya, yang diselesaikan melalui Diversi tetapi tidak jera. Perbuatan Anak dilakukan dengan sengaja dan dengan niat mau balas dendam telah mempermudah saksi 2 melakukan kekerasan terhadap rombongan terhadap korban.

\footnotetext{
${ }^{7}$ Adami Chazawi, 2002, Pelajaran Hukum Pidana, Jakarta, Raja Grafindo Persada, hlm. 69.

${ }^{8}$ Sudarto, 2002, Hukum Pidana Materil, Jakarta, Sinar Grafika, hlm. 28.

${ }^{9}$ Teguh Prasetyo, 2011, Hukum Pidana, Jakarta, Rajawali Pres, hlm.16.
} 
b. Hal-hal yang meringankan: Anak pelaku mengakui kesalahannya, menyesal dan berjanji tidak akan mengulangi lagi. Anak pelaku masih muda usia dan masih dapat diharapkan merubah kelakuannya dimasa yang akan datang.

Kasus yang kedua perkara tindak pidana pembunuhan yang dilakukan oleh anak dengan kronologis Kronologis Kasus yaitu Bermula pada Tahun 2015 pelaku dengan kakak korban sudah saling kenal dikarenakan pelaku sering membeli air tebu pada kakak korban, mereka saling berteman di akun facebook. Pada bulan April 2016 terjadilah percecokan di akun facebook mereka dikarenakan pelaku telah mengedit foto kakak korban. Kemudian sekira pada hari Kamis tanggal 02 Juni 2016 sekira pukul 07.00 WIB, pelaku sedang duduk di depan rumah korban, tiba-tiba kakak korban mengatakan "Orang gila" pada pelaku, kemudian pelaku diam dan pergi ke warnet. Setelah itu terjadilah percecokan kembali di akun facebook mereka sampai pada akhirnya kakak korban memblokir akun facebook pelaku. Keesokan harinya pelaku mendatangi rumah korban dan terjadi pertengkaran mulut diantara mereka, dan akhirnya pelaku meninggalkan korban. Dikarenakan mereka saling bertengkar, maka tidak lagi terjadi komunikasi diantara mereka, maka setiap pelaku melewati rumah korban, pelaku selalu memperhatikan situasi rumahnya, yang mana pelaku mengetahui suara kakak korban berada di kamar atas. Kemudian pada saat bermain ke warnet pelaku membuka cara-cara untuk melakukan pembunuhan.

Pada tanggal 23 Juni 2016 sekira pukul 21.30 WIB, diasaat pelaku sedang melewati rumah korban, pelaku memantau situasi rumah korban apakah ada terparkir becak milik keluarganya. Kemudian sekira pukul 22.00 WIB, pada saat korban dan saksi 1 sedang di depan rumah, pelaku mendatangi mereka dan menanyakan kakak korban untuk meminta uang, kemudia korban memanggilkan kakaknya tetapi pelaku tidak sempat bertemu. Selanjutnya pada tanggal 24 Juni 2016 sekira pukul 00.00 WIB, setelah diketahui becaknya sudah tidak terparkir di depan rumah korban, maka pelaku masuk ke rumah korban dengan cara melalui Lorong samping kiri rumah dan pelaku menggeser kursi sampai ke dinding Lorong tersebut sehingga pelaku dapat memanjat plafon dekat jendela kamar kakaknya, kemudian pelaku masuk kamar tersebut melalui jendela yang tidak terkunci dan pelaku meninggalkan sendal di dekat jendela.

Pelaku duduk di kamar tersebut sekitar 10 menit sambil mengelap pisau yang di bawanya dan sambil memantau kamar mereka memastikan bahwa mereka sudah tidur atau belum. Kemudian sekira pukul 00.15 WIB pelaku turun ke ruang tamu untuk melepas jaket dan topinya lalu di letakkan di tumpukkan boneka, pelaku juga sempat minum air dispenser yang berada di ruang tamu tersebut. Setelah itu, sekira pukul 00.30 WIB, pelaku menuju kamar mereka untuk memastikan sudah pada tidur atau belum, ketika pelaku sudah tidak mendengar suara dari dalam kamar tersebut, pelaku langsung masuk kamar dan menuju kelambu sebelah kiri dan mendekati korban. Setelah itu pelaku mendekap korban dengan kain putih dengan tangan sebelah kiri dan menusuk sebanyak satu (1) kali leher sebelah kiri korban menggunakan pisau dengan tangan kanannya, kemudian pelaku menusuk sebanyak dua (2) kali dada kiri korban, lalu korban sempat melakukan perlawanan sehingga lengan dan punggung tangan kiri korban terkena pisau tersebut hingga posisi tidur korban terlentang. Kemudian pelaku menusuk sebanyak satu (1) kali dada sebelah kanan dan korban sempat menjerit berkali-kali namun pelaku langsung menutup mulut korban dengan kain putih agar suara korban tidak terdengar oleh kakaknya. Setelah itu dikarenakan korban terus meronta-ronta maka pelaku melepaskan kain putih tersebut tiba-tiba kakaknya atau saksi 1 membalikkan badanya dan pada saat itu pelaku ketakutan dan langsung meninggalkan kamar tersebut sambal membawa pisau dan kain putihnya. Kemudian pelaku melarikan diri melewati kamar kakak korban dimana itu adalah tempat pelaku memasuki kamar korban. Setelah itu pelaku turun dan keluar dari rumah tersebut tanpa menggunaakan sendal. Tidak lama kemudian kakak korban bangun dan melihat korban sudah berlumuran darah, maka kakak korban segera membangunkan saksi 1 dan memberitahu kondisi korban yang sudah berlumuran darah dan sudah tidak bernyawa lagi. Kemudian mereka turun keluar rumah untuk meminta tolong pada warga sekitar. Setelah itu pelaku menuju Gp. Meutia sambil mengelap pisau menggunakan kain putih tersebut dan membalut pisau dengan pisau tersebut. Kemudian pelaku bersembunyi di Pajak Pisang dan pergi menuju Jl. T. Umar Gp. Peukan Langsa dan bersembunyi di warung kopi Lorong toko dan menaruh pisau yang di balut kain putih tersebut di samping steling jualan warung kopi tersebut. Kemudian sekira pukul 05.30 WIB pelaku di tangkap oleh Arie Anhar dan Ahmad Fadhil (Anggota 
Polres Langsa) lalu pelaku serta barang bukti pisau yang di balut dengan kain putih bercak darah di bawa ke Kantor Polres Langsa untuk dilakukan penyidikan lebih lanjut.

Hal-hal yang memberatkan dan meringankan, yaitu:

a. Hal yang memberatkan: Perbuatan anak dilakukan terhadap korban yang masih Anak-anak, Perbuatan Anak sangat meresahkan masyarakat.

b. Hal yang meringankan: Anak masih muda diharapkan dapat memperbaiki dirinya, Anak berterus terang serta tidak berbelit-belit dalam memberikan keterangannya dipersidangan, Anak menyesali perbuatannya dan berjanji tidak akan mengulangi lagi perbuatannya, Anak berkeinginan untuk meminta maaf kepada keluarga korban.

Berdasarkan kasus diatas, hakim dalam menjatuhkan pidana terhadap anak tersebut harus mengacu pada Undang-Undang Nomor 11 Tahun 2012 tentang Sistem Peradilan Pidana Anak, karena dalam kasus tersebut pelakunya adalah seorang anak yang dimana diatur dalam UndangUndang Sistem Peradilan Pidana Anak telah disebutkan bahwa batasan umur anak belum mencapai 18 (delapan belas) tahun. Dalam dua kasus diatas pelaku berumur 15 (lima belas) tahun dan 16 (enam belas) tahun. Dalam kasus ini, hakim dalam memutuskan pidana tidak menggunakan diversi dikarenakan kasus diatas adalah kasus yang ancaman pidananya melebihi dari 7 (tujuh) tahun.

Berdasarkan wawancara yang di lakukan oleh penulis kepada salah satu Hakim Anak Pengadilan Negeri Yogyakarta, Hakim dalam menjatuhkan putusan terhadap anak yang melakukan tindak pidana, diharapkan dapat melihat secara objektif batasan usia seseorang dalam mempertimbangkan putusannya, batasan usia di Indonesia sangat beragam, diantaranya berdasarkan Undang-Undang Nomor 23 Tahun 2002 tentang Perlindungan Anak Pasal 1 Ayat (1) "Anak adalah seseorang yang belum berusia 18 (delapan belas) tahun, termasuk anak yang masih di dalam kandungan". Sedangkan dalam Undang-Undang Nomor 11 Tahun 2012 tentang Sistem Peradilan Pidana Anak Pasal 1 Ayat (3) "Anak yang berlonflik dengan hukum adalah anak yang telah berusia 12 (dua belas) tahun, tetapi belum berusia 18 (delapan belas) tahun yang diduga belum melakukan tindak pidana".

Hakim dalam menjatuhkan pidana juga mempertimbangkan terlebih dahulu berdasarkan berat ringannya perbuatan yang dilakukan oleh pelaku, berdasarkan wawancara yang telah penulis lakukan, hakim dalam menjatuhkan pidana terhadap anak yang melakukan tindak pidana, tergantng dari perbuatan yang di lakukan oleh pelaku, jika perbuatan tersebut merugikan dan akan membahayakan masyarakat sekitar, maka hakim akan memberi sanksi penjara, tetapi jika perbuatan tersebut masih dapat di maafkan atau tidak begitu merugikan dan membahayakan masyarakat sekitar maka dapat di serahkan kepada orang tua/ wali. Hal tersebut berdasarkan Undang-Undang Nomor 11 Tahun 2012 tentang Sistem Peradilan Pidana Anak Pasal 70 yaitu "ringannya perbuatan, keadaan pribadi anak, atau keadaan waktu dilakukan perbuatan atau yang terjadi kemudian dapat dijadikan dasar pertimbangan hakim untuk tidak menjatuhkan pidana atau mengenakan tindakan dengan mempertimbangkan segi keadilan dan kemanusiaan".

Seorang hakim dalam menjatuhkan pidana terhadap terdakwa tidak boleh menjatuhkan pidana tersebut kecuali terdapat sekurang-kurangnya dua alat bukti yang sah, sehingga hakim memperoleh keyakinan bahwa suatu tindak pidana benar-benar terjadi dan terdakwalah yang bersalah melakukannya, hal tersebut berdasarkan Pasal 183 KUHAP. Alat bukti sah yang dimaksud terdapat dalam Pasal 184 KUHAP antara lain Keterangan saksi, keterangan ahli, surat, petunjuk, keterangan terdakwa atau hal yang secara umum sudah diketahui sehingga tidak perlu dibuktikan. Putusan pengadilan dituntut untuk memenuhi teori pembuktian, ${ }^{10}$ yaitu saling berhubungan antara bukti yang satu dengan bukti yang lain, misalnya keterangan saksi satu dengan keterangan saksi lain atau saling berhubungan antara keterangan dengan alat bukti yang lain. Ada kemungkinan terjadi suatu perkara yang sudah ada hukumnya tetapi dalam penyelesaiannya berbeda. Dalam proses penyelesaian suatu perkara atau sengketa setepat-tepatnya hakim harus mengetahui terlebih dahulu secara objektif terhadap perkara yang di hadapinya, guna sebagai dasar dalam mempertimbangkan

\footnotetext{
${ }^{10}$ Hari Sasangka, Lily Rosita, 2003, Hukum Pembuktian dalam Perkara Pidana, Bandung, Mandar Maju, hlm. 11.
} 
putusannya. Maka dari itu hakim dalam menentukan putusannya terhadap anak yang melakukan tindak pidana harus berdasarkan KUHAP dan fakta yang terjadi.

\section{Simpulan dan Saran}

\section{A. Simpulan}

Pertimbangan Hakim dalam menjatuhkan sanksi terhadap anak yang melakukan tindak pidana pembunuhan tidak sama dengan pelaku orang dewasa, oleh karena itu hakim dalam mempertimbangkanya harus mengacu pada Undang-Undang Nomor 11 Tahun 2012 tentang Sistem Peradilan Pidana Anak, dimana dalam Undang-Undang tersebut terdapat pengkhususan seperti anak tidak dapat di pidana mati, anak tidak dapat dipidana seumur hidup, dan anak dipidana $1 / 2$ dari ancaman pidana orang dewasa. Pertimbangan Hakim dalam menjatuhkan sanksi terhadap anak yang melakukan tindak pidana pembunuhan juga berdasarkan hal-hal yang memberatkan dalam kasus yang pertama seperti anak telah melakukan pelanggaran hukum dan telah diselesaikan melalui diversi namun tidak jera, perbuatan yang dilakukan memang sengaja dengan niat balas dendam, sedangkan dalam kasus kedua hal-hal yang memberatkan seperti perbuatan Anak dilakukan terhadap korban yang masih Anak-anak dan perbuatan anak sangat meresahkan masyarakat.

\section{B. Saran}

Hakim dalam menjatuhkan hukuman kepada anak yang melakukan tindak pidana pembunuhan diharapkan seadil-adilnya karena hal tersebut merupakan hal yang sangat meresahkan masyarakat sekitar. Dalam menjatuhkan hukuman diharapkan tetap berdasarkan prosedur yang sudah ada.

\section{DAFTAR PUSTAKA}

\section{Buku}

Adami Chazawi, 2002, Pelajaran Hukum Pidana, Jakarta, Raja Grafindo Persada.

B. Simanjuntak, 1984, Kriminologi, Bandung, Tarsito.

Hari Sasangka, Lily Rosita, 2003, Hukum Pembuktian dalam Perkara Pidana, Bandung, Mandar Maju.

J.E, Sahetapy, 1987, Victimologi Sebuah Bunga Rampai, Jakarta, Pustaka Sinar Harapan.

S.R Sianturi, 1996 Asas-Asas Hukum Pidana Indonesia Dan Penerapanya, Jakarta, Alumni AhaemPeteheam.

Sudarto, 2002, Hukum Pidana Materil, Jakarta, Sinar Grafika.

Supramono Gatot, 2000, Hukum Acara Peradilan Anak, Jakarta, Djambatan.

Syekh Khalid bin Abdurrahman, dkk, 2006, Cara Islam Mendidik Anak, cet 1 Yogyakarta, Ad Dawa'.

Teguh Prasetyo, 2011, Hukum Pidana, Jakarta, Rajawali Pres.

\section{Jurnal}

Safrizal, "Pertanggungjawaban Pidana dari Anak Dibawah Umur yang Melakukan Pembunuhan", Lex Crimen, Vol. 2, No. 7, (2013).

\section{Peraturan Perundang-undangan \\ Undang-Undang Nomor 4 Tahun 1979 tentang Kesejahteraan Anak. \\ Undang-Undang Nomor 3 Tahun 1997 tentang Pengadilan Anak.}




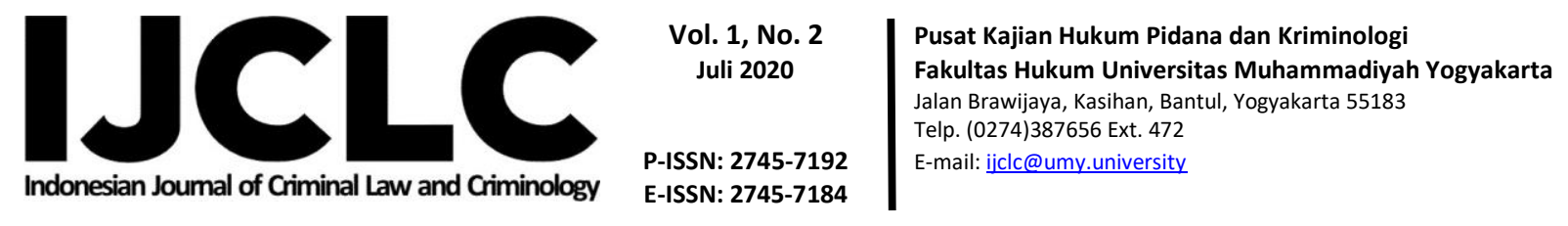

Undang-Undang Nomor 11 Tahun 2012 tentang Sistem Peradilan Anak.

Undang-Undang Nomor 35 Tahun 2014 tentang Perubahan atas Undang-Undang Nomor 23 Tahun 2002 tentang Perlindungan Anak.

Kitab Undang-Undang Hukum Pidana (KUHP).

Kitab Undang-Undang Hukum Acara Pidana (KUHAP). 